\title{
Protease Produced by Endophytic Fungi: A Systematic Review
}

\author{
Victor Hugo Souto Bezerra, Samuel Leite Cardoso, Yris Fonseca-Bazzo (D), Dâmaris Silveira (D), \\ Pérola Oliveira Magalhães (iD) and Paula Monteiro Souza *
}

Natural Products Laboratory, Campus Darcy Ribeiro, School of Health Sciences, University of Brasilia, Brasília 70910-900, DF, Brazil; victor.souto@aluno.unb.br (V.H.S.B.); samuel.leite@aluno.unb.br (S.L.C.); yrisfonseca@unb.br (Y.F.-B.); damaris@unb.br (D.S.); perolamagalhaes@unb.br (P.O.M.)

* Correspondence: paulasouza@unb.br; Tel.: +55-61-3107-1806

Citation: Bezerra, V.H.S.; Cardoso, S.L.; Fonseca-Bazzo, Y.; Silveira, D.; Magalhães, P.O.; Souza, P.M. Protease Produced by Endophytic Fungi: A Systematic Review. Molecules 2021, 26, 7062. https://doi.org/10.3390/ molecules 26227062

Academic Editor: Florenci V. González

Received: 19 October 2021

Accepted: 8 November 2021

Published: 22 November 2021

Publisher's Note: MDPI stays neutral with regard to jurisdictional claims in published maps and institutional affiliations.

Copyright: (c) 2021 by the authors. Licensee MDPI, Basel, Switzerland. This article is an open access article distributed under the terms and conditions of the Creative Commons Attribution (CC BY) license (https:// creativecommons.org/licenses/by/ $4.0 /)$.
Abstract: The purpose of this systematic review was to identify the available literature of production, purification, and characterization of proteases by endophytic fungi. There are few complete studies that entirely exhibit the production, characterization, and purification of proteases from endophytic fungi. This study followed the PRISMA, and the search was conducted on five databases: PubMed, PMC, Science Direct, Scopus Articles, and Web of Science up until 18 May 2021, with no time or language restrictions. The methodology of the selected studies was evaluated using GRADE. Protease production, optimization, purification, and characterization were the main evaluated outcomes. Of the 5540 initially gathered studies, 15 met the inclusion criteria after a two-step selection process. Only two studies optimized the protease production using statistical design and two reported enzyme purification and characterization. The genus Penicillium and Aspergillus were the most cited among the eleven different genera of endophytic fungi evaluated in the selected articles. Six studies proved the ability of some endophytic fungi to produce fibrinolytic proteases, demonstrating that endophytic fungi can be exploited for the further production of agents used in thrombolytic therapy. However, further characterization and physicochemical studies are required to evaluate the real potential of endophytic fungi as sources of industrial enzymes.

Keywords: protease; endophytic fungi; systematic review

\section{Introduction}

The use of chemicals worldwide in different industries has increased the demand for industrial enzymes, mainly due to the need for new sustainable industrial processes that do not affect people's health. Furthermore, enzymes also help preserve an unpolluted environment through their use in waste management, where they are used for effluent treatment and detoxification, renewable energy resources, bioindicators for pollution, and biosensors [1]. With the advancement in technology, a large part of enzymes of industrial and pharmaceutical interest began to be produced on a large scale [2,3]. Proteases are enzymes whose catalytic function is to hydrolyze peptide bonds of proteins into amino acids and peptides. They are part of a large group of enzymes belonging to the class of hydrolase enzymes $[4,5]$.

Currently, proteases are used in several industries such as the pharmaceutical industry, the leather industry, the detergent, and food industries [6,7]. In the food industry, proteases have several functions and are used in different sectors such as cheese-making, bakery, and meat production. The use of proteolytic enzymes in the leather industry has been replacing chemical agents that are toxic and dangerous to the environment. In medical applications, protease can be used to treat a variety of diseases such as cancer, inflammatory diseases, glaucoma, etc. The use of proteases in the detergent industry is responsible for approximately $20 \%$ of the market for commercial enzymes $[3,8,9]$.

Proteases can be produced from plants, animals, and microorganisms. The production of proteases by microorganisms has grown in recent years due to the wide variety of 
enzymes they can produce. They represent about two-thirds of the world's production of proteases [8]. The production of proteases by fungi has grown in recent years due to the wide variety of enzymes produced and the easy separation of mycelia from the culture media when compared to bacteria $[9,10]$. In addition, fungi are generally considered recognized as GRAS (generally regarded as safe), and the proteases produced are mostly extracellular, which facilitates the removal of the enzyme from the fermentation broth [11]. Currently, fungi are responsible for $60 \%$ of the enzymes used in the most diverse industries [12]. A wide variety of fungi are known to be great sources of active and functional proteases. The most used strains for the production of industrial proteases are of the genus Aspergillus and Trichoderma [13].

The term "endophytic" is used to define all the organisms that inhabit the internal tissues of their living hosts during some period of their life cycle [14,15], therefore, endophytic fungi are microorganisms that inhabit the different internal tissues of plants without causing any apparent damage to the host plant [16]. Endophytic fungi have proven to be a source of great potential to produce secondary metabolites and several extracellular enzymes such as amylases, lipases, and proteases as part of their defense mechanisms against other organisms and to obtain the necessary nutrients for their development. The major secondary metabolites and extracellular enzymes synthesized from endophytic fungi, and their potential applications are represented in Figure 1. In recent years, several studies have been carried out to identify endophytic fungi capable of producing proteases with potential industrial or pharmaceutical applications [15,17-19].

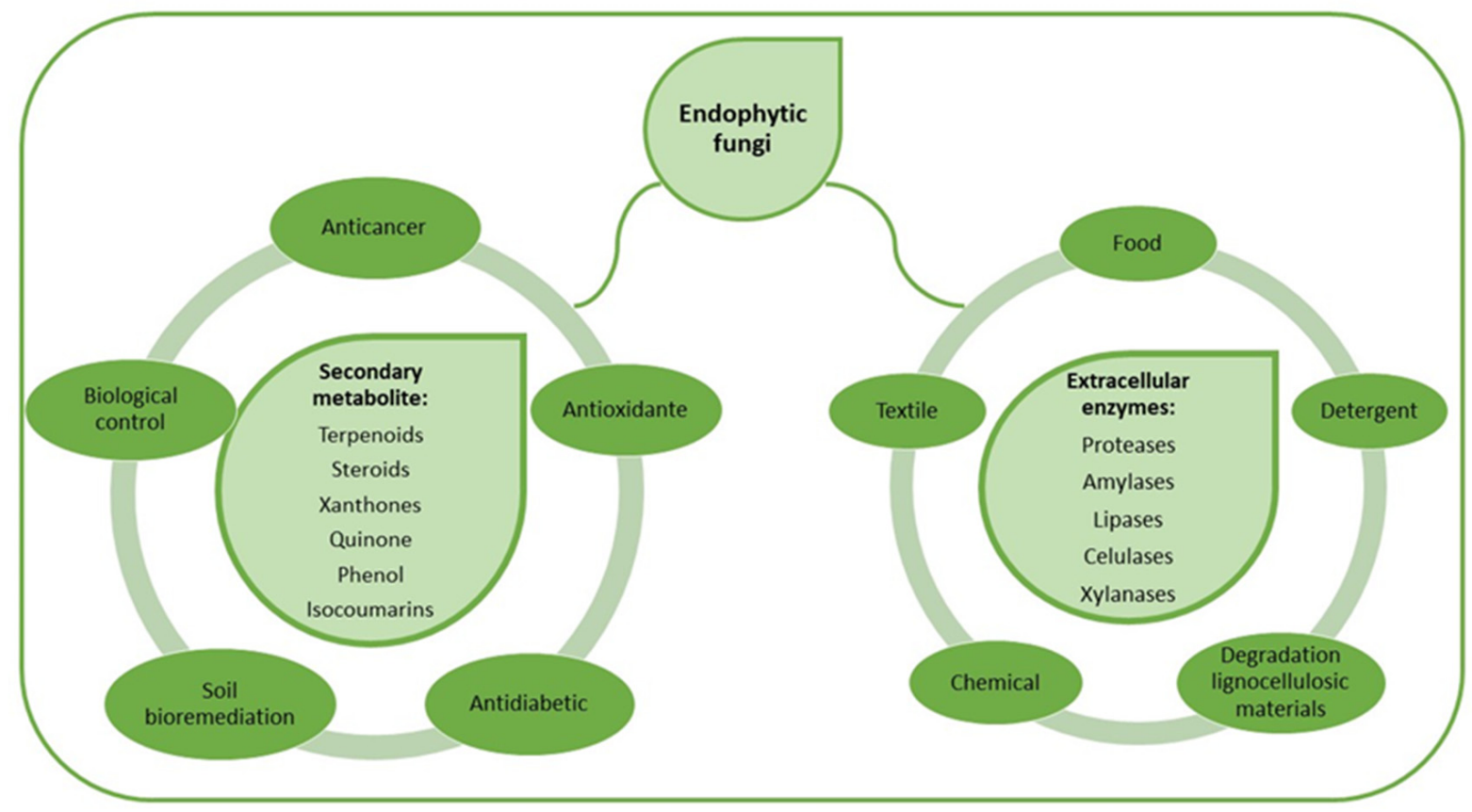

Figure 1. Biotechnology application of secondary metabolites and extracellular enzymes produced from endophytic fungi.

Nowadays, there is a worldwide movement toward prospecting new means of the production of active principles obtained by biotechnological processes. In this context, endophytic fungi have been explored in their biological diversity as new sources of enzymes. Therefore, the isolation and identification of endophytic fungi, the recognition of potential protease producers, and the study of the characteristics of these proteases have become important due to the great biotechnological potential of endophytic fungi as sources of novel proteases that can be useful for specialized industries. Therefore, this review aimed to evaluate and identify the current state of production, characterization, and purification of proteases by endophytic fungi in the available literature. 


\section{Results}

\subsection{Study Selection}

A total of 6028 articles were found after applying the search procedures initially established across the five electronic databases. In the PMC databases were found 2731 articles, 2176 in the Scopus databases, 733 in Science Direct databases, 218 in Web of Science, and 170 in PubMed. After the search process, duplicates were removed, leaving 5261 references. An evaluation of the titles and abstracts of the articles was carried out, thereby excluding 5191 references and retaining 70 references. Any article was identified using the Google Scholar platform. Therefore, supported by the inclusion and exclusion criteria, a review of the full texts was completed, and 15 articles were selected for this review [20-34]. This process led to the exclusion of 55 papers (Appendix A). A flow chart detailing the process of identification, inclusion, and exclusion of studies is shown in Appendix B.

\subsection{Study Characteristics}

A summary of the descriptive characteristics of the included studies is provided in Table 1. The selected articles were carried out in eight different countries. One each from Tunisia [20], Malaysia [30], Australia [33], and the United States [25]; two from Egypt [22,34], Brazil [23,26], and China [24,32]; and five from India [21,27-29,31]. The articles were published between 1994 and 2021 and were written in English. All articles evaluated the production of proteases by endophytic fungi, and nine of the articles performed purification processes and characterization of the proteases produced as described in Table $2[22,24,25,27-30,32,34]$.

The N-terminal amino acid sequence of the purified protease was only performed by three articles. Wu et al. [32] used the automated Edman method to determine the $\mathrm{N}$-terminal sequence of a fibrinolytic protease. The $\mathrm{N}$-terminal sequence of the protease produced by Fusarium sp. (QASSGTPATIRVLVV) appeared to differ strongly from other reported fibrinolytic proteases. The $\mathrm{N}$-terminal sequence of a fibrinolytic protease produced by X. curta was also determined by the automated Edman degradation method. The Nterminal sequence (SNGPLPGGVVWAG) showed differences from previously reported fibrinolytic enzymes from fungi.

\subsection{Synthesis of Results}

\subsubsection{Microorganism}

Among the 15 articles selected for this review, eleven different genera of endophytic fungi were reported as protease producers: Penicillium bilaiae [20], Talaromyces flavus [21]; Mortierella hyalina [21]; Paecilomyces variabilis [21]; Penicillium sp. [21,26], Aspergillus ochraceus [22,34], Aspergillus niger [23], Verticillium sp. [24], Acremonium typhinum [25], Aspergillus sp. [26], Lasiodiplodia pseudotheobromae [27], Xylaria curta [28,29], Penicilium citrinum [30], Fusarium sp. [30,32], and Alternaria alternata [31,33]. In eleven articles, the molecular identification of the fungus involved was mentioned, which species were identified based on ITS-rDNA [22,25,29,31,34,35], 18S rRNA sequence analysis [22,34], PCR amplification of the $\beta$-tubulin gene [21], based on the 28s rDNA region [28,29] and identified on the basis of cultural characteristics, color, and morphology of fruiting bodies and spores [24,31].

\subsubsection{Optimization of Protease Production}

Of the 15 studies evaluated, four carried out processes to optimize the production of proteases. Mefteh et al. [20] used a response surface methodology (RSM) tool and PlackettBurman design to optimize the production of protease by the endophytic fungus P. bilaiae. Elgammal et al. [22] and Rajput et al. [31] adopted a procedure for the optimization of protease production by fungi $A$. ochraceus and A. alternata, respectively, evaluating different parameters such as incubation time, $\mathrm{pH}$, temperature, carbon and nitrogen sources independently while keeping the other parameters constant. Zaferanloo et al. [33] applied a factorial experiment based on a randomized complete design to optimization of protease production by A. alternata. 
Table 1. Summary of the descriptive characteristics of the included studies $(\mathrm{N}=15)$.

\begin{tabular}{|c|c|c|c|c|c|c|c|c|c|c|}
\hline \multirow[b]{2}{*}{ Author } & \multirow{2}{*}{ Country } & \multirow{2}{*}{ Host Plant } & \multirow{2}{*}{ Microorganisms } & \multirow{2}{*}{$\begin{array}{c}\text { Fungal } \\
\text { Identification }\end{array}$} & \multicolumn{4}{|c|}{ Growth Conditions } & \multirow{2}{*}{$\begin{array}{l}\text { Enzyme } \\
\text { Activity }\end{array}$} & \multirow{2}{*}{ Main Conclusions } \\
\hline & & & & & $\mathrm{Ph}$ & $\mathrm{T}\left({ }^{\circ} \mathrm{C}\right)$ & Agitation (rpm) & Time (days) & & \\
\hline Mefteh et al. [20] & Tunisia & $\begin{array}{c}\text { Phoenix } \\
\text { dactylifera } \mathrm{L} \text {. }\end{array}$ & Penicillium bilaiae & ITS-rDNA & 6.26 & 24.5 & 150 & ND & $1086.95 \mathrm{U} / \mathrm{mL}$ & $\begin{array}{l}\text { Plackett-Burman design and RSM approaches } \\
\text { were employed for optimization of culture and } \\
\text { environment conditions and were shown to } \\
\text { significantly enhance protease production. }\end{array}$ \\
\hline $\begin{array}{l}\text { Bhagobaty and } \\
\text { Joshi [21] }\end{array}$ & India & Potentilla fulgens & Talaromycesflavus & $\beta$-tubulin & ND & 25 & 120 & 5 & $34.9 \mathrm{U} / \mathrm{h} / \mathrm{mL}$ & $\begin{array}{l}\text { All the endophytic fungal isolates from } \\
\text { medicinal plant showed production } \\
\text { of protease. } \\
\text { The production of extracellular enzymes was } \\
\text { greater in the liquid medium in comparison to } \\
\text { the plate-based assays. }\end{array}$ \\
\hline$\underset{[22]}{\text { Elgammal et al. }}$ & Egypt & $\begin{array}{l}\text { Ruprechita } \\
\text { salicifolia }\end{array}$ & $\begin{array}{l}\text { Aspergillus } \\
\text { ochraceus }\end{array}$ & 18S rRNA & 8 & 35 & 150 & ND & $292 \mathrm{U} / \mathrm{mL}$ & $\begin{array}{l}\text { The protease production increased by about } \\
7.5 \text {-fold after applying the final optimized } \\
\text { fermentation. The partial purification results } \\
\text { showed that the highly recovered fraction was } \\
\text { at } 60 \% \text { ethanol concentration. }\end{array}$ \\
\hline $\begin{array}{l}\text { El-Khonezy et. al. } \\
{[34]}\end{array}$ & Egypt & $\begin{array}{l}\text { Ruprechita } \\
\text { salicifolia }\end{array}$ & $\begin{array}{l}\text { Aspergillus } \\
\text { ochraceus }\end{array}$ & 18S rRNA & 8 & 35 & 150 & 6 & $800.1 \mathrm{U} / \mathrm{mL}$ & $\begin{array}{l}\text { The enzyme was characterized as } \\
\text { thiol-dependent serine alkaline protease. } \\
\text { Low-cost production medium using different } \\
\text { waste sources was applied to produce } \\
\text { the enzyme. }\end{array}$ \\
\hline Galeano et al. [23] & Brazil & Axonopus purpusii & Aspergillus niger & ITS-rDNA & ND & 30 & 110 & 7 & $12.01 \mathrm{U} / \mathrm{mL}$ & $\begin{array}{l}\text { The ability of the fungus to produce proteases } \\
\text { might reflect the fact that these fungi have } \\
\text { potential as biocontrol agents. }\end{array}$ \\
\hline Li et al. [24] & China & $\begin{array}{l}\text { Trachelospermum } \\
\text { jasminoides }\end{array}$ & Verticillium sp. & Morphology & ND & 28 & 160 & 14 & $3775 \mathrm{U} / \mathrm{mg}$ & $\begin{array}{l}\text { Verticase is a direct degrader of fibrin clot, } \\
\text { most probably playing a negligible role in the } \\
\text { conversion of plasminogen to plasmin. } \\
\text { However, for protein-based medicines, special } \\
\text { care must be taken for an early awareness of } \\
\text { the toxicity. }\end{array}$ \\
\hline $\begin{array}{l}\text { Lindstrom and } \\
\text { Belanger [25] }\end{array}$ & United States & Poa ampla & $\begin{array}{l}\text { Acremonium } \\
\text { typhinum }\end{array}$ & ND & ND & ND & ND & ND & $27 \mathrm{U} / \mathrm{mL}$ & $\begin{array}{l}\text { The regulated nature of proteinase At1 sugges } \\
\text { that its function is important in the symbiotic } \\
\text { interaction of fungus and plants. }\end{array}$ \\
\hline Matias et al. [26] & Brazil & Myrcia guianensis & Aspergillus sp. & Morphology ${ }^{a}$ & 5 & 28 & 150 & 7 & $3.63 \mathrm{U} / \mathrm{mL}$ & $\begin{array}{l}\text { The endophytic fungus with the higher } \\
\text { protease activity demonstrated total efficacy in } \\
\text { the removal of the consolidated biofilm of } \\
\text { S. aureus. }\end{array}$ \\
\hline $\begin{array}{l}\text { Meshram and } \\
\text { Saxena [27] }\end{array}$ & India & Aegle marmelos & $\begin{array}{l}\text { Lasiodiplodia } \\
\text { pseudotheobromae }\end{array}$ & ITS-rDNA & ND & 26 & 130 & 7 & $6514 \mathrm{U} / \mathrm{mL}$ & $\begin{array}{l}\text { The endophytic fungus possesses potential } \\
\text { in vitro fibrinolytic potential. }\end{array}$ \\
\hline$\underset{[28]}{\text { Meshram et al. }}$ & India & Cathranthus roseus & Xylaria curta & $28 \mathrm{~s}$ rDNA & $\mathrm{ND}$ & 26 & 130 & 7 & $34.11 \mathrm{U} / \mathrm{mL}$ & $\begin{array}{l}\text { Submerged fermentation was used to produce } \\
\text { the fibrinolytic enzyme. This protease is a } \\
\text { novel metalloprotease possessing dual activity } \\
\text { including direct degradation of fibrin(ogen) or } \\
\text { by activating the tissue plasminogen. }\end{array}$ \\
\hline
\end{tabular}


Table 1. Cont

\begin{tabular}{|c|c|c|c|c|c|c|c|c|c|c|}
\hline \multirow{2}{*}{ Author } & \multirow{2}{*}{ Country } & \multirow{2}{*}{ Host Plant } & \multirow{2}{*}{ Microorganisms } & \multirow{2}{*}{$\begin{array}{c}\text { Fungal } \\
\text { Identification }\end{array}$} & \multicolumn{4}{|c|}{ Growth Conditions } & \multirow{2}{*}{$\begin{array}{l}\text { Enzyme } \\
\text { Activity }\end{array}$} & \multirow{2}{*}{ Main Conclusions } \\
\hline & & & & & $\mathrm{Ph}$ & $\mathrm{T}\left({ }^{\circ} \mathrm{C}\right)$ & Agitation (rpm) & Time (days) & & \\
\hline $\begin{array}{c}\text { Meshram et al. } \\
\text { [29] }\end{array}$ & India & Cathranthus roseus & Xylaria curta & $\begin{array}{l}\text { ITS-rDNA } \\
\text { 28s rDNA }\end{array}$ & ND & 28 & ND & 15 & $103.56 \mathrm{U} / \mathrm{mL}$ & $\begin{array}{l}\text { The fibrinolytic enzyme xylarinase was } \\
\text { produced by solid substrate fermentation } \\
\text { using rice chaff medium. The purified } \\
\text { metalloprotease showed in vitro thrombolytic } \\
\text { activity and no cytotoxic effect. }\end{array}$ \\
\hline \multirow[b]{2}{*}{ Noor et al. [30] } & \multirow[b]{2}{*}{ Malaysia } & \multirow[b]{2}{*}{ Hibiscus } & Fusarium sp. & $18 \mathrm{~S}$ rRNA $^{\mathrm{a}}$ & ND & ND & ND & ND & $5284 \mathrm{U} / \mathrm{mL}$ & \multirow{2}{*}{$\begin{array}{l}\text { Two fibrinolytic enzymes were purified and } \\
\text { characterized based only on molecular weight } \\
\text { and effect of pH and temperature. }\end{array}$} \\
\hline & & & $\begin{array}{l}\text { Penicillium } \\
\text { citrinum }\end{array}$ & $18 \mathrm{SRNA}{ }^{a}$ & ND & ND & ND & ND & $2200 \mathrm{U} / \mathrm{mL}$ & \\
\hline Wu et al. [32] & China & Chrysanthemum & Fusarium sp. & ITS & ND & 28 & 220 & 6 & $137,000 \mathrm{U}$ & $\begin{array}{l}\text { The fibrinolytic enzyme, named Fu-P, was } \\
\text { purified and identified as a chymotrypsin-like } \\
\text { serine metalloprotease. } \\
\text { May be a potential candidate for thrombolytic } \\
\text { therapy or thrombosis prevention. }\end{array}$ \\
\hline $\begin{array}{l}\text { Zaferanloo et al. } \\
\text { [33] }\end{array}$ & Australia & $\begin{array}{l}\text { Eremophilia } \\
\text { longifolia. }\end{array}$ & $\begin{array}{l}\text { Alternaria } \\
\text { alternata }\end{array}$ & $\begin{array}{l}\text { Morphology } \\
\text { ITS }\end{array}$ & 6.5 & 30 & ND & 7 & $\begin{array}{l}\text { 69.86 BAEE } \\
\text { units/mg }\end{array}$ & $\begin{array}{l}\text { The protease can be applied to cheese making } \\
\text { and in milk-clotting where the fermentation } \\
\text { conditions are suitable to the activation } \\
\text { of protease }\end{array}$ \\
\hline
\end{tabular}

${ }^{a}$ Data presented in earlier studies referenced in the article. ND: No data. 
Table 2. Summary of purification steps, characterization, and kinetic properties of protease from endophytic fungi.

\begin{tabular}{|c|c|c|c|c|c|c|c|}
\hline Author/Year & Purification Method & Microorganisms & $\begin{array}{l}\text { Specific } \\
\text { Activity }\end{array}$ & Purification fold & Molecular Weight (kDa) & $\begin{array}{c}\mathrm{Ph} \\
\text { Optimum }\end{array}$ & $\begin{array}{c}\text { Temperature Optimum } \\
\left({ }^{\circ} \mathrm{C}\right)\end{array}$ \\
\hline Elgammal et al. [22] & $\begin{array}{c}\text { Partial purification } \\
\text { Ethanol fractionation and precipitation }\end{array}$ & Aspergillus ochraceus & $384.2 \mathrm{UI} / \mathrm{mg}$ & 0.11 & ND & 8 & 50 \\
\hline El-Khonezy et. al. [34] & $\begin{array}{c}\text { Ammonium sulfate precipitation } \\
\text { Sephacryl S-200 } \\
\text { DEAE-Sepharose } \\
\text { CM-Sepharose }\end{array}$ & Aspergillus ochraceus & 111,379.5 U/mg protein & 15.3 & 59 & 8 & 50 \\
\hline Li et al. [24] & $\begin{array}{c}\text { Ammonium sulfate precipitation } \\
\text { DEAE-52 column } \\
\text { Sephadex G-75 } \\
\text { Octyl Sepharose } 4 \mathrm{FF} \\
\text { hydrophobic column }\end{array}$ & Verticillium sp. & $3775 \mathrm{UI} / \mathrm{mg}$ & 8.1 & 31 & $9-10$ & $50-60$ \\
\hline $\begin{array}{l}\text { Lindstrom and Belanger } \\
{[25]}\end{array}$ & $\begin{array}{l}\text { Ultrafiltration } 30 \mathrm{Kda} \text {, } \\
\text { Phenylboronate Column } \\
\text { Methanol precipitation }\end{array}$ & Acremonium typhinum & 710 UI/units/ng & ND & 34 & $10-11$ & 37 \\
\hline Meshram and Saxena [27] & $\begin{array}{c}\text { Partial purification } \\
\text { Ammonium sulphate precipitation } \\
\text { and dialyze }\end{array}$ & $\begin{array}{c}\text { Lasiodiplodia } \\
\text { pseudotheobromae }\end{array}$ & $3.56 \mathrm{U} / \mathrm{mg}$ & 2.01 & 80 & ND & ND \\
\hline Meshram et al. [28] & $\begin{array}{l}\text { Ammonium sulfate precipitation } \\
\text { Q-sepharose anion exchange }\end{array}$ & Xylaria curta & $36.67 \mathrm{U} / \mathrm{mg}$ & 9.19 & $\sim 33$ & 8 & 35 \\
\hline Meshram et al. [29] & $\begin{array}{l}\text { Ammonium sulphate } \\
\text { precipitationSephacryl S-300 column }\end{array}$ & Xylaria curta & $9.22 \mathrm{U} / \mathrm{mg}$ & 8.37 & $\sim 33$ & 8 & 35 \\
\hline Noor et al. [30] & $\begin{array}{l}\text { Ammonium sulfate precipitation } \\
\text { Hi-Prep 26/10 Desalting Column } \\
\text { Hi-Trap Benzamidine FF Column }\end{array}$ & Fusarium sp. & $246.92 \mathrm{UI} / \mathrm{mg}$ & 11.2 & $\sim 34$ & 7 & 30 \\
\hline Noor et al. [30] & $\begin{array}{l}\text { Ammonium sulfate precipitation } \\
\text { Hi-Prep 26/10 Desalting Column } \\
\text { Hi-Trap Benzamidine FF Column }\end{array}$ & Penicilium citrinum & $198.2 \mathrm{UI} / \mathrm{mg}$ & 9.7 & $\sim 34$ & 8 & 40 \\
\hline Wu et al. [32] & $\begin{array}{l}\text { Ammonium sulfate precipitation } \\
\text { MonoQ Column } \\
\text { Superdex } 75 \text { Column }\end{array}$ & Fusarium sp. & 76,111 UI/mg & 158.5 & 28 & 8.5 & 45 \\
\hline
\end{tabular}




\subsubsection{Growth Conditions}

Culture medium with different carbon and nitrogen sources were used to produce protease from endophytic fungi. Three studies used Czapek Dox broth or this medium supplemented with other nitrogen and carbon sources for the cultivation of endophytic fungi to induce the protease production $[29,30,35]$. The culture medium used by Li et al. [24] containing $3.0 \%$ sucrose, $0.3 \% \mathrm{NaNO}_{3}, 0.1 \% \mathrm{~K}_{2} \mathrm{HPO}_{4}, 0.1 \%$ yeast extract, $0.05 \% \mathrm{KCl}, 0.05 \%$ $\mathrm{MgSO}_{4} \cdot 7 \mathrm{H}_{2} \mathrm{O}$, and $0.001 \% \mathrm{FeSO}_{4}$ had a protease activity of $3.775 \mathrm{UI} / \mathrm{mg}$. The activity found by Meshram and Saxena [27] by the cultivation of the fungus L. pseudotheobroma in Czapek Dox broth, which is composed of sucrose, $\mathrm{NaNO}_{3}, \mathrm{MgSO}_{4}, \mathrm{KCl}$, and $\mathrm{FeSO}_{4}$ was $3.56 \mathrm{UI} / \mathrm{mg}$. The presence of an organic nitrogen source (yeast extract) may have induced a greater production of protease by the fungus Verticillium sp. [24]. Among the fifteen studies evaluated, twelve used submerged fermentation $(\mathrm{SmF})$, a temperature ranging from $23{ }^{\circ} \mathrm{C}$ to $35^{\circ} \mathrm{C}$, and agitation from 110 to $220 \mathrm{rpm}$ for the endophytic fungus cultivation [20-24,26-28,31-34]. Only one study used solid-state fermentation (SSF) to produce protease [29]. Two other studies did not mention the cultivation method used [25,30].

\subsubsection{Assay for Protease Activity}

Proteolytic activity can be measured by different methods using several substrates. In this systematic review, four selected studies used casein to quantify the enzyme activity $[22,25,33,34]$, three articles performed a protease assay using azocasein $[24,28,36]$, and one article used azoalbumin [25]. Noor et al. [30] estimated the activity using a kit that quantifies protease with a fluorescein thiocarbamoyl-casein derivative (FTC-casein). Zaferanloo et al. [33] applied a QuantiCleaveTM Protease Assay Kit (Thermo-Scientific, Waltham, MA, USA) that uses succinylated casein as a substrate. Four articles performed specific assays for fibrinolytic enzymes, three of which determined the activity via fibrin plate assay [27-29]. Li et al. [24] performed a method slightly modified from Qiuling et al. [35].

\subsubsection{Enzyme Characterization}

The effect of $\mathrm{pH}$ and temperature were reported by ten studies $[20,22,24,25,28-30,32-34]$, and maximum protease activities were observed at value $\mathrm{pH}$ range from 6 to 10 and temperature ranged between $25^{\circ} \mathrm{C}$ and $60^{\circ} \mathrm{C}$. Six proteases showed an optimum pH of 8 [22,28-30,32,34]. Three proteases produced by Fusarium sp. [30], A. alternata [33], and $P$. bilaiae [20] had the highest activity at neutral $\mathrm{pH}(6-7)$. Alkaline proteases produced by Verticillium sp. [24] and A. typhinum [25] showed an activity peak at pH 9-11. Proteases produced by $A$. ochraceus $[22,34]$ and X. curta $[28,29]$ showed an optimum temperature of 50 and $35^{\circ} \mathrm{C}$, respectively.

Seven of the 15 selected articles evaluated the effect of inhibitors on proteases $[22,26,27,30,31,34,36]$. The protease produced by P. bilaiae [20] was completely inhibited by the inhibitor phenylmethylsulfonyl fluoride (PMSF), a serine protease inhibitor. $\mathrm{Li}$ et al. [24] found that the protease produced by Verticillium sp. could be inhibited by PMSF and dithiothreitol (DTT). Protease produced by A. ochraceus was also inhibited by PMSF, however, it was stimulated by DTT and $\beta$-mercaptoethanol [34]. This enzyme was classified as a thiol-dependent-serine protease. Lindstrom and Belanger [25] demonstrated that the protease produced by A. typhinum was partially inhibited by PMSF and dichloroisocoumarin (DCI), also a serine protease inhibitor. The proteases produced by $X$. curta in two studies were completely suppressed by metalloprotease inhibitors such as ethylenediaminetetraacetic acid (EDTA) and ethylene-bis(oxyethylenenitrilo)tetraacetic acid (EGTA) [28,29]. Wu et al. [32] found that the protease produced by Fusarium sp. could be inhibited by PMSF and EDTA.

Eight studies determined the molecular weight of proteases $[24,25,27-30,32,34]$. The identified size of proteases found in the different studies ranged from 28 to $80 \mathrm{kDa}$., and among them, six ranging in size from 28 to $34 \mathrm{kDa}[24,25,28-30,32]$. The highest protease 
produced by Verticillium sp. activity found by Li et al. [24] had a molecular weight of $31 \mathrm{kDa}$.

Meshram et al. [29] was the only study that determined the kinetic parameters of the studied protease produced by the endophytic fungus X. curta. The enzyme $K_{m}$ and $V_{\max }$ for the azocasein substrate were $326 \mu \mathrm{M}$ and $0.13 \mu \mathrm{M} \mathrm{min}^{-1}$, respectively.

The isoelectric point was determined by only one article. Wu et al. [32] isolated and purified a fibrinolytic protease from Fusarium sp., and the protein presented an isoelectric point of 8.1.

One study determined the thermal stability of the protease [20]. A protease produced by fungus P. bilaiae was evaluated for its thermostability. After $10 \mathrm{~min}$ at $70{ }^{\circ} \mathrm{C}$, there was no activity. The enzyme remained stable after $20 \mathrm{~min}$ at $30^{\circ} \mathrm{C}$.

\subsubsection{Purification}

Of the 15 articles selected, eight performed partial or complete purification processes of the protease $[22,24,25,27-30,32]$. Two studies performed a partial purification of the protease produced by A. ochraceus [22] and L. pseudotheobromae [27] using ethanol and ammonium sulfate precipitation, respectively, followed by dialysis. In another study, this same protease from $A$. ochraceus was completely purified using precipitation by ammonium sulfate followed by gel filtration and ion exchange chromatography (Sephacryl S-200, DEAE-Sepharose, and CM-Sepharose columns, respectively) [34]. Lindstrom and Belanger [25] purified a protease produced by A. typhinum using ultrafiltration methods (Centripep-30) followed by passage in a phenylboronate column and finally, precipitation with methanol. Six studies used more complete purification methods with initial precipitation with ammonium sulfate followed by chromatographic processes using ion exchange columns and size exclusion columns. Li et al. [24] purified a fibrinolytic protease produced by Verticillium sp. using a combination of sequential chromatography composed of DEAE52, Sephadex G-75, and hydrophobic columns. A fibrinolytic enzyme produced by X. curta was purified using gel filtration chromatography with a Sephacryl S-300 column [28,29]. Noor et al. [30] used a combination of fast protein liquid chromatography (FPLC) equipped with a Hi-Prep 26/10 Desalting Column and Hi-Trap Benzamidine FF/Hi-Trap IEX Selection Kit to purify proteases produced by Fusarium sp and P. citrinum. Wu et al. [32] purified a fibrinolytic protease produced by Fusarium sp. by employing two steps: passing through the MonoQ column and Superdex 75 column.

\subsection{Risk of Bias}

The articles selected in this study were evaluated using the GRADE tool, as seen in Table 3. Two studies were graded as very low quality and three as low quality. Bhagobaty and Joshi [21] was classified with serious study limitations and publication bias because it used methods with a high degree of interference for the quantification of proteases. Lindstrom and Belanger [25] and Rajput et al. [31] were scored as serious limitation because they did not show the sample size or the assay was not performed in at least triplicate. Noor et al. [30] did not use a specific substrate to assess the fibrinolytic activity of the produced protease by the endophytic fungus. Six studies were rated as moderate quality and three as high quality. Of the 15 articles evaluated, nine were scored as inconsistent because they did not present statistical analysis of the data obtained or did not mention whether tests were performed in triplicate. 
Table 3. Risk of bias in individual studies. Fulfilled GRADE criteria.

\begin{tabular}{|c|c|c|c|c|c|c|}
\hline Author & $\begin{array}{c}\text { Study } \\
\text { Limitation }\end{array}$ & Inconsistency & Indirectness & Imprecision & $\begin{array}{c}\text { Publication } \\
\text { Bias }\end{array}$ & $\begin{array}{l}\text { Overall } \\
\text { Quality }\end{array}$ \\
\hline Mefteh et al. [20] & $\sqrt{ }$ & $\sqrt{ }$ & $\sqrt{ }$ & $\sqrt{ }$ & $\sqrt{ }$ & ++++ \\
\hline Bhagobaty and Joshi [21] & $X$ & $X$ & $\sqrt{ }$ & $\sqrt{ }$ & $X$ & + \\
\hline Elgammal et al. [22] & $\sqrt{ }$ & $\sqrt{ }$ & $\sqrt{ }$ & $\sqrt{ }$ & $\sqrt{ }$ & +++ \\
\hline El-Khonezy et. al. [34] & $\sqrt{ }$ & $\sqrt{ }$ & $\sqrt{ }$ & $\sqrt{ }$ & $\sqrt{ }$ & ++++ \\
\hline Galeano et al. [23] & $\sqrt{ }$ & $\sqrt{ }$ & $X$ & $\sqrt{ }$ & $\sqrt{ }$ & +++ \\
\hline Li et al. [24] & $X$ & $x$ & $\sqrt{ }$ & $X$ & $\sqrt{ }$ & +++ \\
\hline $\begin{array}{c}\text { Lindstrom and } \\
\text { Belanger [25] }\end{array}$ & $X$ & $x$ & $\sqrt{ }$ & $X$ & $\sqrt{ }$ & + \\
\hline Matias et al. [26] & $\sqrt{ }$ & $X$ & $x$ & $\sqrt{ }$ & $\sqrt{ }$ & ++ \\
\hline Meshram and Saxena [27] & $\sqrt{ }$ & $x$ & $\sqrt{ }$ & Unclear & $\sqrt{ }$ & +++ \\
\hline Meshram et al. [28] & $\sqrt{ }$ & $x$ & $\sqrt{ }$ & Unclear & $\sqrt{ }$ & +++ \\
\hline Meshram et al. [29] & $\sqrt{ }$ & $x$ & $\sqrt{ }$ & Unclear & $\sqrt{ }$ & +++ \\
\hline Noor et al. [30] & $\sqrt{ }$ & $X$ & $\sqrt{ }$ & $X$ & $X$ & ++ \\
\hline Noor et al. [30] & $\sqrt{ }$ & $x$ & $\sqrt{ }$ & $x$ & $x$ & ++ \\
\hline Rajput et al. [31] & $\sqrt{ }$ & $\sqrt{ }$ & $\sqrt{ }$ & Unclear & $\sqrt{ }$ & +++ \\
\hline Wu et al. [32] & $x$ & $\sqrt{ }$ & $\sqrt{ }$ & $\sqrt{ }$ & $\sqrt{ }$ & ++++ \\
\hline
\end{tabular}

Grade Factors: $\sqrt{ }$, No Serious Limitations; $X$, Serious Limitations; Unclear, Unable to rate item based on available information.; For overall quality of evidence: +very low; ++ low; +++ moderate; ++++ high.

\section{Discussion}

In recent years, endophytic fungi have been shown to be a source of great potential to produce bioactive compounds with promising applications in agriculture, the environment, the pharmaceutical industry, and the food industry. When compared to other endophytic microorganisms, endophytic fungi produce a wider range of active compounds and these compounds have a broad biological activity [18]. Eleven different genera of endophytic fungi were identified in the evaluated articles (Penicillium, Talaromyces, Mortierella, Paecilomyces, Aspergillus, Verticillium, Acremonium, Lasiodiplodia, Xylaria, Fusarium, and Alternaria). Meshram et al. [28] reported for the first time the production of a fibrinolytic protease by Xylaria species. In this review, only studies that presented quantitative data to produce proteases were selected. However, several other studies have qualitatively evaluated endophytic fungi as potential producers of proteases [36-39].

Nowadays, the analysis of variables through statistical methodologies are widely used to optimize the enzymatic production of several microorganisms. They are quick and easy methodologies and are quite reliable [40]. However, few studies using statistical techniques have been conducted for protease optimization by endophytic fungi. Only two studies used statistical methodologies to optimize the production of proteases by endophytic fungi. Mefteh et al. [20] used two methods, Plackett-Burman design and Box Behnken design, experimental designs for response surface methodology. Zaferanloo et al. [33] used a factorial experiment based on a randomized complete design as a statistical tool for optimizing protease production. The use of statistical techniques is a better tool for optimizing enzyme production than the traditional one-variable-at-a-time method, as they allow not only to assess the individual influence that each factor exerts on enzyme production, but also the interaction between them.

The production of proteases by microorganisms is greatly influenced by the components present in the culture medium, especially carbon and nitrogen sources, metal ions, some physical factors ( $\mathrm{pH}$ and temperature), incubation time, and inoculum size [10]. It is known that proteases are usually produced in the stationary phase of growth, and therefore, carbon and nitrogen sources exert regulatory effects on enzyme synthesis [41]. The way each fungus uses carbon and nitrogen sources is individual and depends on several factors, so there is no specific culture medium to produce proteases, as the ideal $\mathrm{pH}$ and temperature vary from fungus to fungus. Two studies used the Czapek Dox as culture medium, which contains sucrose as a carbon source and sodium nitrate as a nitrogen source [27,28]. 
Meshram et al. [29] was the only study that used the solid-state fermentation technique and evaluated the influence of different agro-industrial residues (rice chaff, wheat bran, eggshell, orange peel, and banana peel) on enzyme production by the fungus X. curta. Four articles evaluated the effect of different carbon and nitrogen sources on protease production. Mefteh et al. [20] found mannose and malt extract as the best carbon sources in the production of protease by the fungus P. bilaiae. Elgammal et al. [22] showed that dextrin was the best source of carbon and peptone was the best source of nitrogen to produce protease by the fungus $A$. ochraceus. Two studies that evaluated the best sources of carbon and nitrogen to produce protease by the fungus $A$. alternata found that glucose and soybean were the best source of carbon and yeast extract was the best source of nitrogen [31,33].

In addition to carbon and nitrogen sources, physical factors also influence the induction or repression of protease production such as initial $\mathrm{pH}$, temperature speed agitation, and inoculum size. Among the physical parameters, $\mathrm{pH}$ and temperature are important regulators of enzyme production and the stability of substrates in the culture medium because it can affect the chemical structure of enzymes, causing their denaturation and loss of catalytic activity [22]. Three studies indicated that some physical parameter negatively or positively influenced the production of proteases. Mefteh et al. [20] evaluated the influence of the initial temperature and $\mathrm{pH}$ of the medium on the production of protease from the endophytic fungus $P$. bilaiae. Elgammal et al. [22] performed tests to measure the effect of initial $\mathrm{pH}$, temperature, inoculum level, and agitation on protease production by the endophytic fungus A. ochraceus. Meshram et al. [29] analyzed how the parameters of temperature, incubation time, and particle size influenced the production of proteases from the endophytic fungus X. curta.

The discovery of new sources that produce proteases such as endophytic fungi could be a good strategy to produce these enzymes at an industrial level. The production of a wide range of proteases with different thermodynamic characteristics implies the wide applicability of these enzymes in the food, pharmaceutical, textile, paper, and sanitizing products industries.

Alkaline proteases could be used as bio-additive compounds in the textile and food industries and to increase cleaning power [36,42,43]. In this review, Li et al. [24] and Lindstrom and Belanger [25] found fungal alkaline proteases of $\mathrm{pH} 9,10$, and 11, respectively, however, there was no assay for the application of these enzymes. The works published by Meshram et al. [28] and [29], Noor et al. [30], and Wu et al. [32] demonstrated the fibrinolytic protease application with optimal $\mathrm{pH} 8$.

The kinetic parameters as well as the thermal stability and the isoelectric point have only been presented in a few studies [20,29]. The enzymatic characterization is important to evaluate the economic and industrial application of these enzymes. It is of fundamental importance to understand the functioning and characteristics of each protease in order to apply them in processes of industrial magnitude [44].

The enzymatic activity must be evaluated by analyzing the substrate in the reaction, and the type of protease. Characterization in serine, cysteine, or metalloprotease can be performed by testing with inhibitors, as demonstrated by Li et al. [24], Mefteh et al. [20], Wu et al. [32], Meshram et al. [29], Lindstrom and Belanger [25], and Meshram et al. [28].

The analysis of the $\mathrm{N}$-terminal sequence of proteins allows for a further comparison with proteins already studied in previous works. The N-terminal sequence analysis of the fibrinolytic protease found by Meshram et al. [29] allowed for the discovery of a bifunctional enzyme with no homology to those deposited fibrinolytic proteases in the databases. According to Luo et al. [45], the analysis of the N-terminal sequence of proteins allows for confirmation of the identity of the protein, thus providing additional information on mass and subunits.

The protein purification process, in general, involves a series of actions to isolate a specific protein present in a complex mixture and remove unwanted compounds. An ideal purification process should be carried out with the fewest possible steps to avoid loss of the desired protein and be a low-cost process. However, the processes to be 
used will depend on the final application of the enzyme. The first step in recovering extracellular proteases involves separating cell biomass from the fermentation broth. The next step involves concentrating the proteases, which can be conducted through filtration or precipitation methods. In the following steps, generally, procedures involving column chromatography are performed. Among the selected articles, two performed partial purification that involved enzyme precipitation processes with ethanol [22] and ammonium sulfate [27] followed by dialysis. Six studies applied ammonium sulfate precipitation methods followed by chromatographic processes using ion exchange chromatography, size exclusion chromatography $[26,30,31,34,36]$, and affinity chromatography for enzyme purification [30]. One study used ultrafiltration methods (Centripep-30) followed by passage in a phenyl boronate column and finally, precipitation with methanol [25].

As mentioned, proteases are constantly used by the pharmaceutical industry to produce cosmetics and medicines. Recently, endophytic fungi have been used as precursors to produce proteases with potential fibrinolytic action that can play an important role in thrombolytic therapy. Among the articles in this review, six explored the potential of endophytic fungi to produce fibrinolytic proteases. The endophytic fungi Verticillium sp. [24], L. pseudotheobromae [27], X. curta [28,29], Fusarium sp. [30,32], and P. citrinum [30] were able to produce fibrinolytic proteases, with potential industrial application for the formulation of agents used in thrombolytic therapy.

\section{Materials and Methods}

This systematic review was conducted following the PRISMA (Preferred Reporting Items for Systematic Reviews and Meta-Analysis) Checklist [46]. The protocol was not registered because it is a systematic review of in vitro studies. This type of systematic review is not suitable for inclusion in the PROSPERO (International Prospective Register of Systematic Reviews).

\subsection{Information Sources and Search Strategy}

To conduct this systematic review, specific research strategies were carried out in five bibliographic databases (Appendix C): PubMed, PMC, Science Direct, Scopus Articles, and Web of Science. A separate search was carried out in the Google Scholar database in case any relevant study was not selected during the search in the five electronic databases. The search for articles in electronic databases was performed independently by two authors on the same day to ensure that the search was carried out correctly. The research included only scientific articles published before 10 September 2021 with no time or language restrictions. A reference manager software was used to remove duplicate references (EndNote, Thomson Reuters, Toronto, ON, Canada).

\subsection{Study Selection}

The selection of the articles was conducted in two stages. In stage one, the titles and abstracts of all articles were analyzed independently by two authors. This first review selected articles that seemed to meet the inclusion criteria based on the title and abstract. When any divergence appeared between the two initial authors, a third author was consulted to resolve it. Studies that did not have any inclusion criteria or that were not related to the topic of this review were excluded. In stage two, two authors read the entire text of the remaining articles and excluded those that did not meet the inclusion criteria. Finally, three authors reviewed the remaining articles and selected the articles evaluated in this review.

\subsection{Eligibility Criteria}

\subsubsection{Inclusion Criteria}

For this review, articles were selected that showed the enzymatic activity of proteases produced by endophytic fungi of any species, evaluated the optimization of the produc- 
tion of proteases, and performed purification processes (complete or partial) or enzyme characterization (temperature, $\mathrm{pH}$, isoelectric point, stability).

\subsubsection{Exclusion Criteria}

Articles that presented any of the following items were excluded: (1) studies performed with non-endophytic fungal species; (2) papers with only screening qualitative studies or did not quantify the protease activity; (3) reviews, letters, personal opinions, book chapters, and conferences; (4) studies that did not mention the production of proteases by endophytic fungi; and (5) studies written in non-English language. For this review, only endophytic fungi isolated from organisms belonging to the kingdom Plantae were considered. Studies involving mycorrhizal fungi, sometimes classified as endophytic fungi, were disregarded as they were considered to be different species [47].

\subsection{Data Collection Process and Data Items}

Data collection from the selected articles was carried out by two authors independently. The third author was responsible for checking the collected data. Any disagreement was resolved after discussion between the three authors and mutual agreement. From the articles included in this review, the following data were collected: year of publication, author(s), country and site, fungus species, plant species from which the fungus was isolated, protease activity, growth condition, purification processes, and data from enzyme characterization.

\subsection{Risk of Bias in Individual Studies}

An assessment tool of the quality of evidence from studies was employed as the methodology in the evaluation of selected studies in this review [48]. The GRADE tool used was adapted for in vitro studies, since no other specific methodology for quality analysis has been developed so far. Two authors independently ranked each item according to its quality as 'high', 'moderate', 'low', or 'very low'. Disagreements were resolved by a third author.

\subsection{Risk of Bias in Individual Studies}

Production, optimization, purification, and characterization of proteases from endophytic fungi were the main evaluated outcomes.

\section{Limitations}

After analyzing the articles included in this review, some points need to be considered. Among the selected articles, only two performed enzyme optimization processes. Only two had optimized enzyme production with the aid of statistical techniques, showing that statistical methodologies should be used more in optimization processes, since evaluating the effects of the physical and chemical parameters using the method of one variable at a time, in the view of the authors of this review, only evaluates the individual effects of these on the parameters in enzyme production and does not actually optimize production. The GRADE tool used was adapted for in vitro studies, since no other specific methodology for quality analysis has been developed thus far. Only four studies were rated as high quality, showing that most of the studies evaluated had some risk bias or were not able to fully answer the review questions defined in this systematic review.

\section{Conclusions}

This systematic review showed different species of endophytic fungi as excellent producers of proteases, with potential applications in different industrial segments. The genus Penicillium was the most cited among the eleven different genera of endophytic fungi evaluated in the selected articles, followed by Aspergillus, Alternaria, and Xylaria. It is known that the use of statistical methodologies is a better tool to optimize the growth conditions for enzyme production, however, only two used statistical methodologies to optimize the 
protease production. This demonstrates a lack of studies that use more effective techniques to improve the yield of proteases so that they can be produced on a large scale. Enzyme characterization is an important process that is performed to understand the functionalities and characteristics of a protease to assess its economic and industrial potential. Only two studies carried out characterization of the protease found. In the evaluated articles, different sources of carbon and nitrogen were used in the culture media. This infers that those endophytic fungi can produce proteases with a wide variety of carbon and nitrogen sources. Six studies proved the ability of some endophytic fungi to produce fibrinolytic proteases, demonstrating that endophytic fungi can be exploited as producers of fibrinolytic proteases for the further production of agents used in thrombolytic therapy. Therefore, the great potential of endophytic fungi as a source of proteases was observed with potential application in the pharmaceutical industry.

Author Contributions: Conceptualization, P.M.S., D.S. and P.O.M.; Methodology, P.M.S., V.H.S.B., and S.L.C.; Data curation, P.M.S., Y.F.-B. and P.O.M.; Writing-original draft preparation, V.H.S.B., S.L.C. and P.M.S.; Writing-review and editing, P.M.S., Y.F.-B., D.S. and P.O.M.; Supervision, P.M.S.; Funding acquisition, P.M.S. All authors have read and agreed to the published version of the manuscript.

Funding: This research was funded by FAPDF (Federal District Research Foundation, Brazil) and CAPES (Coordination for the Improvement of Higher Education, Brazil).

Institutional Review Board Statement: Not applicable.

Informed Consent Statement: Not applicable.

Data Availability Statement: This study did not report any data.

Conflicts of Interest: The authors declare no conflict of interest.

\section{Appendix A}

Table A1. Excluded articles and reasons for exclusion $(n=55)$.

\begin{tabular}{cc}
\hline References & Reason for Exclusion \\
\hline Abou El-Kassem et al. [49] & 4 \\
\hline Alberto et al. [50] & 2 \\
\hline Amobonye et al. [51] & 3 \\
\hline Ayob and Simarani [42] & 2 \\
\hline Baazeem et al. [43] & 2 \\
\hline Bajwa et al. [52] & 1 \\
\hline Bastos et al. [53] & 4 \\
\hline Bensaci et al. [54] & 2 \\
\hline Bezerra et al. [55] & 2 \\
\hline Bezerra et al. [56] & 2 \\
\hline Borgi et al. [57] & 1 \\
\hline Bryant et al. [58] & 4 \\
\hline Cairney and Burke [59] & 1 \\
\hline da Silva et al. [60] & 2 \\
\hline da Silva et al. [61] & 1 \\
\hline De Azevedo Silva et al. [62] & 2 \\
\hline Devi et al. [63] & 2 \\
\hline El-Gendy [64] & 1 \\
\hline
\end{tabular}


Table A1. Cont.

\begin{tabular}{|c|c|}
\hline References & Reason for Exclusion \\
\hline Fouda et al. [38] & 2 \\
\hline George et al. [65] & 2 \\
\hline Gupta et al. [36] & 2 \\
\hline Hassan [66] & 2 \\
\hline Indarmawan et al. [67] & 1 \\
\hline Jagannath et al. [68] & 2 \\
\hline Jalili et al. [69] & 2 \\
\hline Kapoor et al. [70] & 2 \\
\hline Katoch et al. [71] & 2 \\
\hline Katoch et al. [72] & 2 \\
\hline Kudryavtseva et al. [73] & 5 \\
\hline Kumar et al. [74] & 4 \\
\hline Kuzhalvaymani et al. [75] & 1 \\
\hline Leake and Read [76] & 1 \\
\hline Lindstrom et al. [77] & 2 \\
\hline Liu et al. [78] & 1 \\
\hline Lopez-Llorca et al. [79] & 4 \\
\hline Lumyong et al. [80] & 2 \\
\hline Maccheroni et al. [81] & 2 \\
\hline Martins et al. [82] & 2 \\
\hline Meshram et al. [39] & 2 \\
\hline Mishra et al. [83] & 2 \\
\hline Monteiro et al. [84] & 2 \\
\hline Orlandelli et al. [85] & 2 \\
\hline Prathyusha et al. [86] & 2 \\
\hline Rajagopal et al. [87] & 2 \\
\hline Rajesh and Ravishankar Rai [88] & 2 \\
\hline Reddy et al. [89] & 2 \\
\hline Santos et al. [90] & 2 \\
\hline Seshagiri and Tallapragada [91] & 2 \\
\hline Sharma et al. [92] & 2 \\
\hline Silva et al. [93] & 2 \\
\hline Sopalun and Iamtham [94] & 2 \\
\hline Sopalun et al. [95] & 2 \\
\hline Swetha et al. [96] & 2 \\
\hline Wu et al. [97] & 2 \\
\hline Zaferanloo et al. [98] & 2 \\
\hline
\end{tabular}

Reasons for exclusion:

- $\quad$ Studies performed with non-endophytic fungal species $(n=9)$;

- Papers with only screening studies (qualitative analysis) or did not quantify the protease activity $(n=39)$; 
- Reviews, letters, personal opinions, book chapters, and conference abstracts $(n=1)$;

- Studies that do not mention protease production by endophytic fungi $(n=5)$; and

- Studies written in non-English language $(n=1)$.

Appendix B. PRISMA

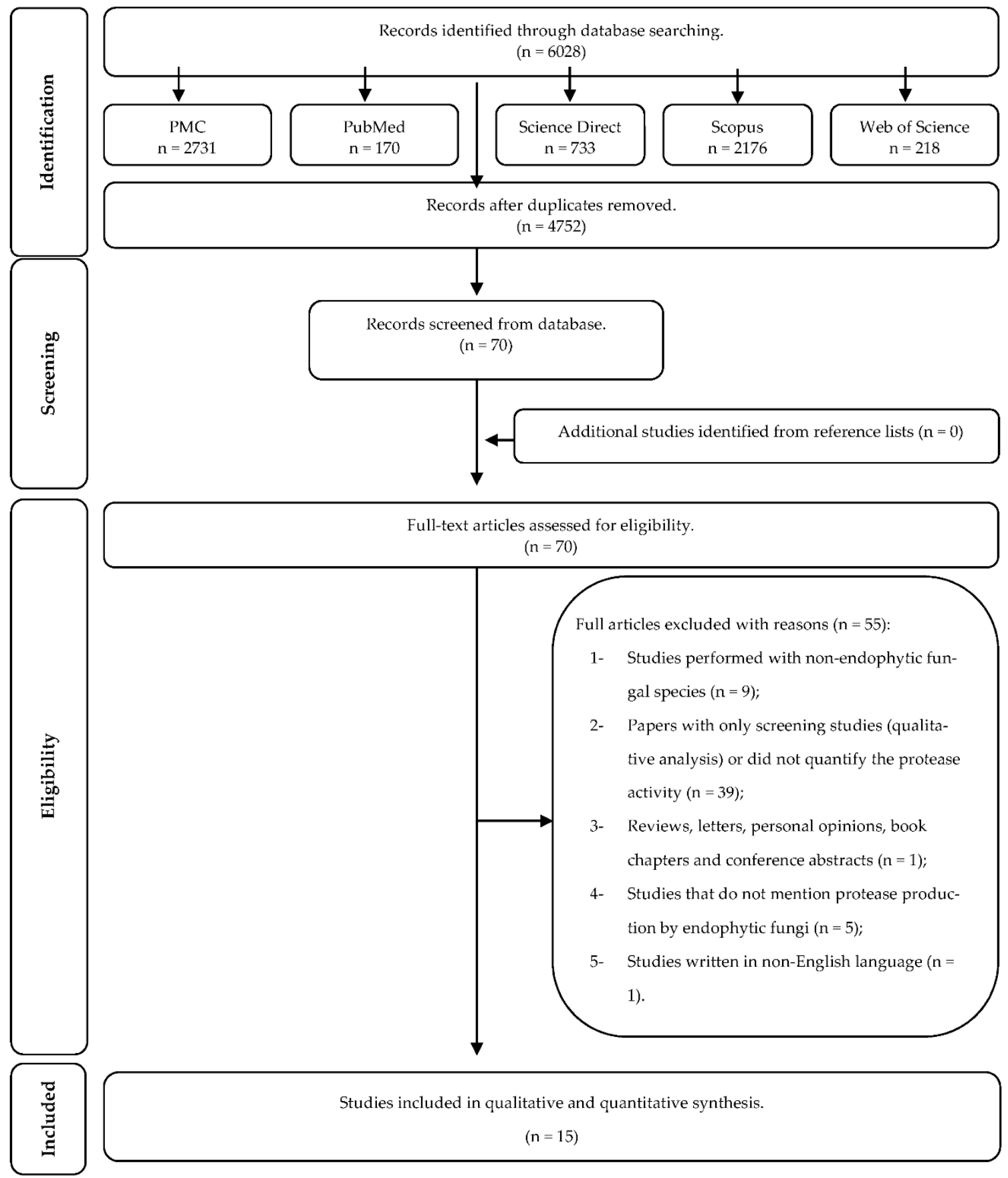

Figure A1. Flow Diagram of literature search and selection criteria adapted from. 


\section{Appendix C}

Table A2. Search strategies with appropriated key words and MeSH terms.

\section{Database}

PMC

(10 September 2021)

\section{Search}

(("peptide hydrolases"[MeSH Terms] OR ("peptide"[All Fields] AND

"hydrolases"[All Fields]) OR "peptide hydrolases"[All Fields] OR "protease"[All

Fields]) OR ("peptide hydrolases"[MeSH Terms] OR ("peptide"[All Fields] AND

"hydrolases"[All Fields]) OR "peptide hydrolases"[All Fields] OR

("proteolytic"[All Fields] AND "enzyme"[All Fields]) OR "proteolytic enzyme" [All Fields]) OR ("peptide hydrolases"[MeSH Terms] OR ("peptide"[All

Fields] AND "hydrolases"[All Fields]) OR "peptide hydrolases"[All Fields] OR "peptidase"[All Fields]) OR ("peptide hydrolases"[MeSH Terms] OR

("peptide"[All Fields] AND "hydrolases"[All Fields]) OR "peptide hydrolases"[All

Fields] OR "proteinase"[All Fields])) AND ((endophytic[All Fields] AND

("fungi"[MeSH Terms] OR "fungi"[All Fields] OR "fungus"[All Fields])) OR (endophytic[All Fields] AND ("microbiology"[Subheading] OR

"microbiology"[All Fields] OR "fungi"[All Fields] OR "fungi"[MeSH Terms])) OR mycoendophyte[

All Fields])

PubMed

(10 September 2021)

Scopus

(10 September 2021)

(protease OR proteolytic enzyme OR peptidase OR proteinase) AND (endophytic fungus OR endophytic fungi OR mycoendophyte)

( ( ( ( protease ) OR proteinase ) OR peptidase ) OR proteolytic AND enzyme $))$ AND ( ( ( endophytic AND fungi ) OR endophytic AND fungus ) OR mycoendophytics ) AND ( LIMIT-TO ( DOCTYPE, "ar" ) OR LIMIT-TO ( DOCTYPE, "sh" ))

(protease OR proteolytic enzyme OR peptidase OR proteinase) AND (endophytic

Science Direct

(10 September 2021) fungus OR endophytic fungi OR mycoendophyte) - Limited to: Research articles, Discussion, News, Short communications and Other
Web of Science

(10 September 2021)
\#1 TS = (protease OR proteolytic enzyme OR peptidase OR proteinase) AND \#2 TS $=$ (endophytic fungus OR endophytic fungi OR mycoendophyte) COMBINE \#1 and \#2
Google Scholar (10 September 2021) (protease OR proteolytic enzyme OR peptidase OR proteinase) AND (endophytic fungus OR endophytic fungi OR mycoendophyte)

\section{References}

1. Ahuja, S.K.; Ferreira, G.M.; Moreira, A.R. Utilization of enzymes for environmental applications. Crit. Rev. Biotechnol. 2004, 24, 125-154. [CrossRef]

2. Kumar, V.; Sangwan, P.; Singh, D.; Kaur Gill, P. Global Scenario of Industrial Enzyme Market.; Nova Science Publishers: New York, NY, USA, 2014; pp. 173-196.

3. Razzaq, A.; Shamsi, S.; Ali, A.; Ali, Q.; Sajjad, M.; Malik, A.; Ashraf, M. Microbial proteases applications. Front. Bioeng. Biotechnol. 2019, 7, 110. [CrossRef]

4. Rao, M.B.; Tanksale, A.M.; Ghatge, M.S.; Deshpande, V.V. Molecular and biotechnological aspects of microbial proteases. Microbiol. Mol. Biol. Rev. 1998, 62, 597-635. [CrossRef] [PubMed]

5. Vojcic, L.; Pitzler, C.; Körfer, G.; Jakob, F.; Martinez, R.; Maurer, K.-H.; Schwaneberg, U. Advances in protease engineering for laundry detergents. New Biotechnol. 2015, 32, 629-634. [CrossRef]

6. Nirmal, N. Fungal proteases: An overview. Int. J. Biotechnol. Biosci. 2011, 1, 1-40.

7. Savitha, S.; Sadhasivam, S.; Swaminathan, K.; Lin, F.H. Fungal protease: Production, purification and compatibility with laundry detergents and their wash performance. J. Taiwan Inst. Chem. Eng. 2011, 42, 298-304. [CrossRef]

8. Tavano, O.L. Protein hydrolysis using proteases: An important tool for food biotechnology. J. Mol. Catal. B Enzym. 2013, 90, 1-11. [CrossRef]

9. Veloorvalappil, N.J.; Robinson, B.S.; Selvanesan, P.; Sasidharan, S.; Kizhakkepawothail, N.U.; Sreedharan, S.; Prakasan, P.; Moolakkariyil, S.J.; Sailas, B. Versatility of microbial proteases. Adv. Enzym. Res. 2013, 1, 39-51.

10. Haddar, A.; Fakhfakh-Zouari, N.; Hmidet, N.; Frikha, F.; Nasri, M.; Kamoun, A.S. Low-cost fermentation medium for alkaline protease production by Bacillus mojavensis A21 using hulled grain of wheat and sardinella peptone. J. Biosci. Bioeng. 2010, 110, 288-294. [CrossRef] [PubMed] 
11. Sandhya, C.; Sumantha, A.; Szakacs, G.; Pandey, A. Comparative evaluation of neutral protease production by Aspergillus oryzae in submerged and solid-state fermentation. Process. Biochem. 2005, 40, 2689-2694. [CrossRef]

12. Mandal, S.; Banerjee, D. Proteases from endophytic fungi with potential industrial applications. In Recent Advancement in White Biotechnology Through Fungi; Springer: Cham, Switzerland, 2019; pp. 319-359.

13. Gurumallesh, P.; Alagu, K.; Ramakrishnan, B.; Muthusamy, S. A systematic reconsideration on proteases. Int. J. Biol. Macromol. 2019, 128, 254-267. [CrossRef] [PubMed]

14. Gouda, S.; Das, G.; Sen, S.K.; Shin, H.-S.; Patra, J.K. Endophytes: A treasure house of bioactive compounds of medicinal importance. Front. Microbiol. 2016, 7, 1538. [CrossRef]

15. Aly, A.H.; Debbab, A.; Proksch, P. Fungal endophytes: Unique plant inhabitants with great promises. Appl. Microbiol. Biotechnol. 2011, 90, 1829-1845. [CrossRef]

16. Bacon, C.W.; White, J. Microbial Endophytes; CRC Press: Boca Raton, FL, USA, 2000.

17. Rana, K.; Kour, D.; Yadav, A.; Kumar, V.; Dhaliwal, H. Endophytic microbes from wheat: Diversity and biotechnological applications for sustainable agriculture. In Proceeding of the 57th Association of Microbiologist of India \& International Symposium on "Microbes and Biosphere: What's New What's Next", Assam, India, 24-27 November 2016.

18. Rana, K.L.; Kour, D.; Sheikh, I.; Dhiman, A.; Yadav, N.; Yadav, A.N.; Rastegari, A.A.; Singh, K.; Saxena, A.K. Endophytic fungi: Biodiversity, ecological significance, and potential industrial applications. In Recent Advancement in White Biotechnology through Fungi; Springer: Cham, Switzerland, 2019; pp. 1-62.

19. Corrêa, R.C.G.; Rhoden, S.A.; Mota, T.R.; Azevedo, J.L.; Pamphile, J.A.; de Souza, C.G.M.; Polizeli, M.d.L.T.d.M.; Bracht, A.; Peralta, R.M. Endophytic fungi: Expanding the arsenal of industrial enzyme producers. J. Ind. Microbiol. Biotechnol. 2014, 41, 1467-1478. [CrossRef] [PubMed]

20. Mefteh, F.; Frikha, F.; Daoud, A.; Chenari Bouket, A.; Luptakova, L.; Alenezi, F.N.; Al-Anzi, B.S.; Oszako, T.; Gharsallah, N.; Belbahri, L. Response surface methodology optimization of an acidic protease produced by Penicillium bilaiae isolate TDPEF30, a newly recovered endophytic fungus from healthy roots of date palm trees (Phoenix dactylifera L.). Microorganisms $2019,7,74$. [CrossRef]

21. Bhagobaty, R.K.; Joshi, S.R. Enzymatic activity of fungi endophytic on five medicinal plant species of the pristine sacred forests of Meghalaya, India. Biotechnol. Bioprocess. Eng. 2012, 17, 33-40. [CrossRef]

22. Elgammal, E.W.; El-Khonezy, M.I.; Ahmed, E.F.; Abd-Elaziz, A.M. Enhanced production, partial purification, and characterization of alkaline thermophilic protease from the endophytic fungus Aspergillus ochraceus BT21. Egypt. Pharm. J. 2020, 19, 338-349.

23. Galeano, R.M.S.; Franco, D.G.; Chaves, P.O.; Giannesi, G.C.; Masui, D.C.; Ruller, R.; Corrêa, B.O.; da Silva Brasil, M.; Zanoelo, F.F. Plant growth promoting potential of endophytic Aspergillus niger 9-p isolated from native forage grass in Pantanal of Nhecolândia region, Brazil. Rhizosphere 2021, 18, 100332. [CrossRef]

24. Li, Y.; Shuang, J.L.; Yuan, W.W.; Huang, W.Y.; Tan, R.X. Verticase: A fibrinolytic enzyme produced by Verticillium sp. Tj33, an endophyte of Trachelospermum jasminoides. J. Integr. Plant. Biol. 2007, 49, 1548-1554. [CrossRef]

25. Lindstrom, J.T.; Belanger, F.C. Purification and characterization of an endophytic fungal proteinase that is abundantly expressed in the infected host grass. Plant. Physiol. 1994, 106, 7-16. [CrossRef]

26. Matias, R.R.; Sepúlveda, A.M.G.; Batista, B.N.; de Lucena, J.; Albuquerque, P.M. Degradation of Staphylococcus aureus biofilm using hydrolytic enzymes produced by amazonian endophytic fungi. Appl. Biochem. Biotechnol. 2021, 193, 2145-2161. [CrossRef]

27. Meshram, V.; Saxena, S. Potential fibrinolytic activity of an endophytic Lasiodiplodia pseudotheobromae species. 3 Biotech. 2016, 6, 114. [CrossRef]

28. Meshram, V.; Saxena, S.; Paul, K. Xylarinase: A novel clot busting enzyme from an endophytic fungus Xylaria curta. J. Enzym. Inhib. Med. Chem. 2016, 31, 1502-1511. [CrossRef]

29. Meshram, V.; Saxena, S.; Paul, K.; Gupta, M.; Kapoor, N. Production, purification and characterisation of a potential fibrinolytic protease from endophytic Xylaria curta by solid substrate fermentation. Appl. Biochem. Biotechnol. 2017, 181, 1496-1512. [CrossRef] [PubMed]

30. Noor, Z.M.; Ahmad, M.S.; Ariffin, Z.Z. Purification and characterisation of fibrinolytic enzymes from endophytic fungi and Lignosus rhinocerus. J. Teknol. 2016, 78, 53-57.

31. Rajput, K.; Chanyal, S.; Agrawal, P.K. Optimization of protease production by endophytic fungus, Alternaria alternata isolated from gymnosperm tree-Cupressus torulosa D Don. World J. Pharm. Pharmaceut. Sci. 2016, 5, 1034-1054.

32. Wu, B.; Wu, L.; Chen, D.; Yang, Z.; Luo, M. Purification and characterization of a novel fibrinolytic protease from Fusarium sp. CPCC 480097. J. Ind. Microbiol. Biotechnol. 2009, 36, 451-459. [CrossRef]

33. Zaferanloo, B.; Quang, T.D.; Daumoo, S.; Ghorbani, M.M.; Mahon, P.J.; Palombo, E.A. Optimization of protease production by endophytic fungus, Alternaria alternata, isolated from an Australian native plant. World J. Microbiol. Biotechnol. 2014, 30, 1755-1762. [CrossRef]

34. El-Khonezy, M.I.; Elgammal, E.W.; Ahmed, E.F.; Abd-Elaziz, A.M. Detergent stable thiol-dependant alkaline protease produced from the endophytic fungus Aspergillus ochraceus BT21: Purification and kinetics. Biocatal. Agric. Biotechnol. 2021, $35,102046$. [CrossRef]

35. Qiuling, X.; Jian, L.; Ling, Z. A new assay of fibrinolytic enzymes. Prog. Biochem. Biophys. 2001, $28,582-583$.

36. Gupta, S.; Chaturvedi, P. Research, Phytochemical screening and extracellular enzymatic enumeration of foliar endophytic fungal isolates of Centella asiatica (L.) Urban. Int. J. Pharm. Sci. Rev. Res. 2015, 35, 21-24. 
37. Sunitha, V.; Nirmala Devi, D.; Srinivas, C. Extracellular enzymatic activity of endophytic fungal strains isolated from medicinal plants. World J. Agric. Sci. 2013, 9, 1-9.

38. Fouda, A.H.; Hassan, S.E.-D.; Eid, A.M.; Ewais, E.E.-D. Biotechnological applications of fungal endophytes associated with medicinal plant Asclepias sinaica (Bioss.). Ann. Agric. Sci. 2015, 60, 95-104. [CrossRef]

39. Meshram, V.; Kapoor, N.; Saxena, S. Endophytic Fusarium isolates from Aegle marmelos in Western Ghats of India and their fibrinolytic ability. Sydowia 2016, 68, 119-130.

40. Zhu, M.J.; Cheng, J.R.; Chen, H.T.; Deng, M.C.; Xie, W.H. Optimization of neutral protease production from Bacillus subtilis: Using agroindustrial residues as substrates and response surface methodology. Biotechnol. Appl. Biochem. 2013, 60, 336-342. [CrossRef] [PubMed]

41. Gupta, R.; Beg, Q.; Khan, S.; Chauhan, B. An overview on fermentation, downstream processing and properties of microbial alkaline proteases. Appl. Microbiol. Biotechnol. 2002, 60, 381-395.

42. Ayob, F.W.; Simarani, K. Endophytic filamentous fungi from a Catharanthus roseus: Identification and its hydrolytic enzymes. Saudi Pharm. J. 2016, 24, 273-278. [CrossRef]

43. Baazeem, A.; Almanea, A.; Manikandan, P.; Alorabi, M.; Vijayaraghavan, P.; Abdel-Hadi, A. In Vitro Antibacterial, Antifungal, Nematocidal and Growth Promoting Activities of Trichoderma hamatum FB10 and Its Secondary Metabolites. J. Fungi 2021, 7, 331. [CrossRef]

44. Souza, P.M.; Aliakbarian, B.; Ferreira Filho, E.X.; Magalhães, P.O.; Junior, A.P.; Converti, A.; Perego, P. Kinetic and thermodynamic studies of a novel acid protease from Aspergillus foetidus. Int. J. Biol. Macromol. 2015, 81, 17-21. [CrossRef]

45. Luo, Y.; Matejic, T.; Ng, C.-K.; Nunnally, B.; Porter, T.; Raso, S.; Rouse, J.; Shang, T.; Steckert, J. Technology, Characterization and analysis of biopharmaceutical proteins. Sep. Sci. Technol. 2011, 10, 283-359.

46. Page, M.J.; McKenzie, J.E.; Bossuyt, P.M.; Boutron, I.; Hoffmann, T.C.; Mulrow, C.D.; Shamseer, L.; Tetzlaff, J.M.; Akl, E.A.; Brennan, S.E.; et al. The PRISMA 2020 statement: An updated guideline for reporting systematic reviews. BMJ 2021, 372, n71. [CrossRef] [PubMed]

47. Brundrett, M.C. Understanding the roles of multifunctional mycorrhizal and endophytic fungi. In Microbial Root Endophytes; Springer: Berlin/Heidelberg, Germany, 2006; pp. 281-298.

48. Huguet, A.; Hayden, J.A.; Stinson, J.; McGrath, P.J.; Chambers, C.T.; Tougas, M.E.; Wozney, L. Judging the quality of evidence in reviews of prognostic factor research: Adapting the GRADE framework. Syst. Rev. 2013, 2, 1-12. [CrossRef]

49. Abou El-Kassem, L.; Hawas, U.W.; El-Souda, S.; Ahmed, E.F.; El-Khateeb, W.; Fayad, W. Anti-HCV protease potential of endophytic fungi and cytotoxic activity. Biocatal. Agric. Biotechnol. 2019, 19, 101170. [CrossRef]

50. Alberto, R.N.; Costa, A.T.; Polonio, J.C.; Santos, M.S.; Rhoden, S.A.; Azevedo, J.L.; Pamphile, J.A. Extracellular enzymatic profiles and taxonomic identification of endophytic fungi isolated from four plant species. Genet. Mol. Res. 2016, 15, gmr15049016. [CrossRef] [PubMed]

51. Amobonye, A.; Bhagwat, P.; Pandey, A.; Singh, S.; Pillai, S. Biotechnological potential of Beauveria bassiana as a source of novel biocatalysts and metabolites. Crit. Rev. Biotechnol. 2020, 40, 1019-1034. [CrossRef] [PubMed]

52. Bajwa, R.; Abuarghub, S.; Read, D.J. The biology of mycorrhiza in the Ericaceae: X. The utilization of proteins and the production of proteolytic enzymes by the mycorrhizal endophyte and by mycorrhizal plants. New Phytol. 1985, 101, 469-486. [CrossRef]

53. Bastos, A.; Cardoso, P.G.; Santos, I.A.F.M.; Trento, M.V.C.; Porto, L.C.J.; Marcussi, S. Enzymatic Modulators from Induratia spp. Curr. Microbiol. 2020, 77, 3603-3611. [CrossRef]

54. Bensaci, O.A.; Daoud, H.; Lombarkia, N.; Rouabah, K. Formulation of the endophytic fungus Cladosporium oxysporum Berk. \& M.A. Curtis, isolated from Euphorbia bupleuroides subsp. luteola, as a new biocontrol tool against the black bean aphid (Aphis fabae Scop.). J. Plant. Prot. Res. 2015, 55, 80-87.

55. Bezerra, J.D.; Nascimento, C.C.; Barbosa Rdo, N.; da Silva, D.C.; Svedese, V.M.; Silva-Nogueira, E.B.; Gomes, B.S.; Paiva, L.M.; Souza-Motta, C.M. Endophytic fungi from medicinal plant Bauhinia forficata: Diversity and biotechnological potential. Braz. J. Microbiol. 2015, 46, 49-57. [CrossRef]

56. Bezerra, J.D.; Santos, M.G.; Svedese, V.M.; Lima, D.M.; Fernandes, M.J.; Paiva, L.M.; Souza-Motta, C.M. Richness of endophytic fungi isolated from Opuntia ficus-indica Mill. (Cactaceae) and preliminary screening for enzyme production. World J. Microbiol. Biotechnol. 2012, 28, 1989-1995. [CrossRef]

57. Borgi, I.; Dupuy, J.W.; Blibech, I.; Lapaillerie, D.; Lomenech, A.M.; Rebai, A.; Ksantini, M.; Bonneu, M.; Gargouri, A. Hyperproteolytic mutant of Beauveria bassiana, a new biological control agent against the tomato borer. Agron. Sustain. Dev. 2016, 36, 60. [CrossRef]

58. Bryant, M.K.; Schardl, C.L.; Hesse, U.; Scott, B. Evolution of a subtilisin-like protease gene family in the grass endophytic fungus Epichloë festucae. BMC Evol. Biol. 2009, 9, 168. [CrossRef]

59. Cairney, J.W.G.; Burke, R.M. Extracellular enzyme activities of the ericoid mycorrhizal endophyte Hymenoscyphus ericae (Read) Korf and Kernan: Their likely roles in decomposition of dead plant tissue in soil. Plant. Soil 1998, 205, 181-192. [CrossRef]

60. Da Silva, M.A.; Santos, C.; Pérez-Nevado, F.; Lima, N.; da Silva Bentes, J.L. Enzymatic activity and process of initial infection of guarana plant (Paullinia cupana) by pathogenic and endophytic strains of Colletotrichum Guaranicola. Rev. Fitotec. Mex. 2021, 44, 67-75. 
61. Da Silva, R.R.; da Rosa, N.G.; Goncalves de Oliveira, L.C.; Juliano, M.A.; Juliano, L.; Rosa, J.C.; Cabral, H. Biochemical properties and catalytic specificity of a novel neutral serine peptidase secreted by fungus Pyrenochaetopsis sp. Appl. Biochem. Biotechnol. 2019, 187, 1158-1172. [CrossRef] [PubMed]

62. De Azevedo Silva, F.; Liotti, R.G.; Ana Paula deAraújo, B.; De Melo Reis, É.; Passos, M.B.S.; Dos Santos, E.L.; Sampaio, O.M.; Januário, A.H.; Branco, C.L.B.; Da Silva, G.F.; et al. Diversity of cultivable fungal endophytes in Paullinia cupana (Mart.) Ducke and bioactivity of their secondary metabolites. PLOS ONE 2018, 13, e0195874. [CrossRef]

63. Devi, N.N.; Prabakaran, J.J.; Wahab, F. Phytochemical analysis and enzyme analysis of endophytic fungi from Centella asiatica. Asian Pac. J. Trop. Biomed. 2012, 2 (Suppl. S3), S1280-S1284. [CrossRef]

64. El-Gendy, M.M. Keratinase production by endophytic Penicillium spp. Morsy1 under solid-state fermentation using rice straw. Appl. Biochem. Biotechnol. 2010, 162, 780-794. [CrossRef]

65. George, T.K.; SubaidaBeevi, S.; Asok, A.K.; Shaikmoideen, J.M. Plant growth promoting endophytic yeast Geotrichum candidum (JX 477426) from roots of Bruguiera cylindrica. J. Microbiol. Biotechnol. Food Sci. 2019, 9, 267-272.

66. Hassan, S.E.D. Plant growth-promoting activities for bacterial and fungal endophytes isolated from medicinal plant of Teucrium polium L. J. Adv. Res. 2017, 8, 687-695. [CrossRef]

67. Indarmawan, T.; Mustopa, A.Z.; Budiarto, B.R.; Tarman, K. Antibacterial ativity of extracellular protease isolated from an algicolous fungus Xylaria psidii KT30 against gram-positive bacteria. HAYATI J. Biosci. 2016, 23, 73-78. [CrossRef]

68. Jagannath, S.; Konappa, N.; Lokesh, A.; Bhuvaneshwari; Dasegowda, T.; Udayashankar, A.C.; Chowdappa, S.; Cheluviah, M.; Satapute, P.; Jogaiah, S. Bioactive compounds guided diversity of endophytic fungi from Baliospermum montanum and their potential extracellular enzymes. Anal. Biochem. 2021, 614, 114024. [CrossRef] [PubMed]

69. Jalili, B.; Bagheri, H.; Azadi, S.; Soltani, J. Identification and salt tolerance evaluation of endophyte fungi isolates from halophyte plants. Int. J. Environ. Sci. Technol. 2020, 17, 3459-3466. [CrossRef]

70. Kapoor, N.; Rajput, P.; Abu Mushtaque, M.; Gambhir, L. Bio-prospecting fungal endophytes of high altitude medicinal plants for commercially imperative enzymes. Biosci. Biotechnol. Res. Commun. 2018, 11, 370-375.

71. Katoch, M.; Salgotra, A.; Singh, G. Endophytic fungi found in association with Bacopa monnieri as potential producers of industrial enzymes and antimicrobial bioactive compounds. Braz. Arch. Biol. Technol. 2014, 57, 714-722. [CrossRef]

72. Katoch, M.; Singh, A.; Singh, G.; Wazir, P.; Kumar, R. Phylogeny, antimicrobial, antioxidant and enzyme-producing potential of fungal endophytes found in Viola odorata. Ann. Microbiol. 2017, 67, 529-540. [CrossRef]

73. Kudryavtseva, N.N.; Pobedinskaya, M.A.; Balabko, P.N.; Kokaeva, L.Y.; Zaichik, B.T.; Kutuzova, N.A.; Azarkovich, M.I.; Elansky, S.N.; Valueva, T.A. The proteolytic activity and virulence of Alternaria alternata strains, isolated from tomato. Mikol. I Fitopatol. 2017, 51, 110-116.

74. Kumar, A.; Jha, P.K.; Kumar, R.; Kumar, K.; Sedolkar, V. Antibacterial activity, phytochemical and enzyme analysis of crude extract of endophytic fungus, Alternaria sp. isolated from an ethanobotanical medicinal plant Tridax procumbens. Int. J. Pharmacogn. Phytochem. Res. 2015, 7, 1111-1115.

75. Kuzhalvaymani, K.; Jacquline, E.L.; Subha, T.S. Production, characterization of proteases by solid state fermentation using sugarcane bagasse by Warcupiella spinulosa. Int. J. Sci. Technol. Res. 2019, 8, 384-393.

76. Leake, J.R.; Read, D.J. Proteinase activity in mycorrhizal fungi: I. The effect of extracellular $\mathrm{pH}$ on the production and activity of proteinase by ericoid endophytes from soils of contrasted pH. New Phytol. 1990, 115, 243-250. [CrossRef]

77. Lindstrom, J.T.; Sun, S.; Belanger, F.C. A novel fungal protease expressed in endophytic infection of Poa species. Plant. Physiol. 1993, 102, 645-650. [CrossRef] [PubMed]

78. Liu, X.; Jia, J.; Atkinson, S.; Camara, M.; Gao, K.; Li, H.; Cao, J. Biocontrol potential of an endophytic Serratia sp G3 and its mode of action. World J. Microbiol. Biotechnol. 2010, 26, 1465-1471. [CrossRef]

79. Lopez-Llorca, L.V.; Gómez-Vidal, S.; Monfort, E.; Larriba, E.; Casado-Vela, J.; Elortza, F.; Jansson, H.B.; Salinas, J.; Martín-Nieto, J. Expression of serine proteases in egg-parasitic nematophagous fungi during barley root colonization. Fungal Genet. Biol. 2010, 47, 342-351. [CrossRef] [PubMed]

80. Lumyong, S.; Lumyong, P.; McKenzie, E.H.; Hyde, K.D. Enzymatic activity of endophytic fungi of six native seedling species from Doi Suthep-Pui National Park, Thailand. Can. J. Microbiol. 2002, 48, 1109-1112. [CrossRef] [PubMed]

81. Maccheroni, W.; Araujo, W.L.; Azevedo, J.L. Ambient pH-regulated enzyme secretion in endophytic and pathogenic isolates of the fungal genus Colletotrichum. Sci. Agric. 2004, 61, 298-302. [CrossRef]

82. Martins, J.; Veríssimo, P.; Canhoto, J. Isolation and identification of Arbutus unedo L. fungi endophytes and biological control of Phytophthora cinnamomi in vitro. Protoplasma 2021, 1-9. [CrossRef] [PubMed]

83. Mishra, A.; Gond, S.K.; Sharma, V.K.; Verma, S.K.; Kumar, J.; Singh, D.K.; Kumar, A.; Pandey, P.; Kharwar, R.N. Characterization of Pseudofusficoccum adansoniae, an endophytic fungus residing in photosynthetic root of Tinospora cordifolia, a medicinal plant. Proc. Natl. Acad. Sci. India Sect. B-Biol. Sci. 2019, 89, 1319-1326. [CrossRef]

84. Monteiro, M.C.P.; Tavares, D.G.; Nery, E.M.; de Queiroz, M.V.; Pereira, O.L.; Cardoso, P.G. Enzyme production by Induratia spp. isolated from coffee plants in Brazil. Braz. Arch. Biol. Technol. 2020, 63. [CrossRef]

85. Orlandelli, R.C.; de Almeida, T.T.; Alberto, R.N.; Polonio, J.C.; Azevedo, J.L.; Pamphile, J.A. Antifungal and proteolytic activities of endophytic fungi isolated from Piper hispidum Sw. Braz. J. Microbiol. 2015, 46, 359-366. [CrossRef]

86. Prathyusha, P.; Rajitha Sri, A.B.; Satya Prasad, K. Diversity and enzymatic activity of foliar endophytic fungi isolated from medicinal plants of indian dry deciduous forest. Der Pharm. Lett. 2015, 7, 244-251. 
87. Rajagopal, K.; Meenashree, B.; Binika, D.; Joshila, D.; Tulsi, P.S.; Arulmathi, R.; Kathiravan, G.; Tuwar, A. Mycodiversity and biotechnological potential of endophytic fungi isolated from hydrophytes. Curr. Res. Environ. Appl. Mycol. 2018, 8, 172-182. [CrossRef]

88. Rajesh, P.S.; Ravishankar Rai, V. Hydrolytic enzymes and quorum sensing inhibitors from endophytic fungi of Ventilago madraspatana Gaertn. Biocatal. Agric. Biotechnol. 2013, 2, 120-124. [CrossRef]

89. Reddy, P.V.; Lam, C.K.; Belanger, F.C. Mutualistic fungal endophytes express a proteinase that is homologous to proteases suspected to be important in fungal pathogenicity. Plant. Physiol. 1996, 111, 1209-1218. [CrossRef] [PubMed]

90. Santos, I.R.; Abdel-azeem, A.M.; Mohesien, M.T.; Piekutowska, M.; Sheir, D.H.; da Silva, L.L.; Castro, C.D.S.; Carvalho, D.D.C.; Bezerra, J.D.P.; Saad, H.A.; et al. Insights into the bioprospecting of the endophytic fungi of the medicinal plant Palicourea rigida Kunth (Rubiaceae): Detailed biological activities. J. Fungi 2021, 7, 689. [CrossRef] [PubMed]

91. Seshagiri, S.; Tallapragada, P. Optimization of process parameters for high biomass, alpha-amylase and protease enzyme by Piriformospora indica using mathematical model. Res. J. Pharm. Biol. Chem. Sci. 2015, 6, 916-922.

92. Sharma, H.; Rai, A.K.; Chettri, R.; Nigam, P.S. Bioactivites of Penicillium citrinum isolated from a medicinal plant Swertia chirayita. Arch. Microbiol. 2021, 203, 5173-5182. [CrossRef] [PubMed]

93. Silva, R.L.D.O.; Luz, J.S.; Da Silveira, E.B.; Cavalcante, U.M.T. Endophytic fungi of Annona spp.: Isolation, enzymatic characterization of isolates and plant growth promotion in Annona squamosa L. seedlings. Acta Bot. Bras. 2006, 20, 649-655. [CrossRef]

94. Sopalun, K.; Iamtham, S. Isolation and screening of extracellular enzymatic activity of endophytic fungi isolated from Thai orchids. South. Afr. J. Bot. 2020, 134, 273-279. [CrossRef]

95. Sopalun, K.; Laosripaiboon, W.; Wachirachaikarn, A.; Iamtham, S. Biological potential and chemical composition of bioactive compounds from endophytic fungi associated with thai mangrove plants. South. Afr. J. Bot. 2021, 141, 66-76. [CrossRef]

96. Swetha, S.; Varma, A.; Padmavathi, T. Statistical evaluation of the medium components for the production of high biomass, $\alpha$-amylase and protease enzymes by Piriformospora indica using Plackett-Burman experimental design. 3 Biotech. 2014, 4, 439-445. [CrossRef]

97. Wu, B.; Wu, L.; Ruan, L.; Ge, M.; Chen, D. Screening of endophytic fungi with antithrombotic activity and identification of a bioactive metabolite from the endophytic fungal strain CPCC 480097. Curr. Microbiol. 2009, 58, 522-527. [CrossRef] [PubMed]

98. Zaferanloo, B.; Virkar, A.; Mahon, P.J.; Palombo, E.A. Endophytes from an Australian native plant are a promising source of industrially useful enzymes. World J. Microbiol. Biotechnol. 2013, 29, 335-345. [CrossRef] [PubMed] 